\title{
蛍光体を用いたエンジン筒内ガス温度速度同時計測 *
}

\author{
染矢 聡 $^{* 1, * 2}$, 内田 光則 ${ }^{* 2}$, 大倉 康裕 ${ }^{* 3}$, 佐藤 義久 ${ }^{* 3}$, 岡本 孝司 ${ }^{* 2}$
}

\section{Combined Measurement of Temperature and Velocity of a Gaseous Flow in an Optical Engine Using Phosphor Particles}

\author{
Satoshi SOMEYA ${ }^{* 1, * 2}$, Mitsunori UCHIDA, Yasuhiro OKURA, Yoshihisa SATO and Koji OKAMOTO \\ ${ }^{* 1}$ Energy Technology Research Institutes, Advanced Industrial Science and Technology \\ Namiki 1-2-1, Tsukuba, Ibaraki, 305-8564, Japan
}

A combined velocity and temperature measurement method using a high speed camera, a single-pulsed UV laser and temperature sensitive phosphor particles had been proposed. The method was extended to a measurement of a gaseous flow at high temperature. The phosphor particles are the powders of rare earth-doped ceramics, which have strong sensitivity to temperature, resulting in a small intensity and a short lifetime of luminescence at high temperature. The phosphor material was painted on the solid wall in an engine cylinder, and the instantaneous wall temperature was measured, in order to confirm the applicability of phosphor particles to the in-cylinder measurement. The measured wall temperature increased with the increase of measured pressure in the cylinder. The measured wall temperature distribution and its temperature had good correlation with a change of calculated gas temperature from the pressure. Then, the combined temperature and velocity measurement of the gas flow in the cylinder was performed. The temperature was calculated from the lifetime and the velocity was obtained from the phosphor particle images during a single decay. Two dimensional velocity and temperature distribution in the engine cylinder was successfully visualized. The temperature changes dependently on the crank angle agreed qualitatively with the gas temperature estimated from the pressure. However, the absolute values of the measured temperature had differences from the estimated ones.

Key Words : Flow Visualization, Laser-Aided Diagnostics, Heat and Fluid Flow Measurement, Phosphor, Lifetime, Temperature, Velocity

\section{1. 緒言}

近年，カメラや光源の著しい発達に伴い，あらゆる時間・空間スケールで流れの可視化が行われている. 速度 分布については PIV(particle image velocimetry)が商品化されて定着しているが，特に気体の二次元温度分布計測に 関しては，計測手法がほとんど存在しない.

一方，エネルギー環境問題の観点から，ガスエンジンの高効率化，高温動作用のヒートポンプ，固体酸化物型 燃料電池など高温のガス流れと深い関係を持つ技術の開発が進んでいる. 例えば高効率かつ低 $\mathrm{NO}_{\mathrm{x}}$ な内燃機関を 実現する燃焼方式として開発されている予混合圧縮自己着火然焼方式(1)(2)では, 空気と燃料の予混合気を燃焼室内 に導入し，ピストンの圧縮によって高温・高圧とすることで多点同時に自己着火させる.この方式では，低負荷 側は失火，高負荷側はノックにより運転範囲が限定されており，その運転範囲の狭さにより未だ実用化に至って いない，そこで，高負荷時に発生するノッキングを抑制するため，燃焼前の筒内ガスを温度成層化させて，ガス の自着火のタイミングを空間的にずらすことでガス圧力上昇率を緩和させることが検討されている(3).つまり，

\footnotetext{
*原稿受付 2010 年12月 25 日

*1 正員, 産業技術総合研究所 (厂305-8564 茨城県つくば市並木 1-2-1)

*2 正員, 東京大学大学院 新領域創成科学研究科

*3 正員, (株) 本田技術研究所四輪 R\&D センター

E-mail: s.someya@aist.go.jp
} 
この方法の開発では, 着火直前の筒内ガス温度分布をいかに適切にコントロールするかが鍵となっており, これ を実証・実現するために，温度分布を把握することが重要である．また，このような温度分布を作る際に EGR (Exhaust Gas Recirculation)を利用しており，筒内流動によりEGR 分布のコントロールが可能である.このような 背景を元に筒内事象解析を行うため, 温度分布と速度分布の同時計測が望まれる. しかし，筒内ガスの二次元断 面温度・速度の同時計測はこれまで困難であった。

既存の二次元温度計測技術には様々なものがある. 例えばレーザー誘起蛍光法(LIF)は研究例が多く, マイクロ ・マクロスケールの温度, $\mathrm{pH}$, 物質濃度の二次元計測に多用されている(4) (8). 気体中の多次元温度分布計測につ いては，近年，レーリー散乱を利用する方法の提案 ${ }^{(9)}$ が見られるが，未だ開発段階の技術であり，LIF の場合は 多くは水溶液を対象とした手法である. 蛍光染料は乾燥した状態では発光しないものがほとんぞであり, 主に水 溶液の温度測定に利用されている。

蛍光体の燐光発光強度・スペクトルや燐光寿命が温度に依存寸ることが古くから知られている．無機蛍光体の

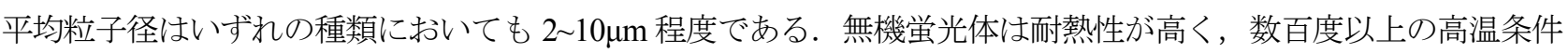
でも発光強度・寿命が温度依存性を示寸.これらを用いた既往の研究の多く ${ }^{(10)}(15)$ は固体壁面温度を測定対象とし ている. 蛍光体の発する燐光強度が比較的弱いことからイメージインテンシファイア付きのカメラを用いて強度 法による温度測定をした例が多いが，LIF 同様に二色法を適用寸る必要があるため，複雑な撮影システムを用い ていた. 最近では長谷川ら ${ }^{(16)}$ が YAG:Dy蛍光体による二色法を用いてエンジン筒内ガスの温度計測を行っている.

近年，筆者らは，まずオイルの流れを対象として，燐光染料を PIV 粒子に焼結させた感温粒子を作成し，比較 的シンプルな測定系で撮影した画像から温度速度分布を求める方法を提案してきた ${ }^{(17,18)}$. そこで本研究では, 温 度依存性を持った燐光を発する無機質蛍光体に着目し, 高温環境でも利用できる感温性無機質蛍光体を PIV の卜 レーサ粒子として適用することで，任意の二次元断面における高温ガスの温度・速度分布同時計測を可能とする 手法の開発を行う。ここで，二色法にしばしば利用されるイメージインテンシファイア付きカメラはショットノ イズが多く, PIV に必ずしも適さない. また, 光路を二系統に分岐し, 透過域の狭い光学フィルタの利用は画像 輝度を低下させ, 長時間露光を必要とする要因となる. そのため本研究ではイメージインテンシファイアや分光 光学系を要しない寿命法を利用する.

今回適用する手法は燐光の寿命を利用することで，1 台の高速度カメラを利用したシンプルな計測系により， 任意の二次元断面の温度場・速度場を同時に, 高時間・空間分解能で計測できる. 1 台のシングルパルスレーザ 一と 1 台のカメラのみで計測系を構築するため, 比較的安価で, かつ, 光学的アクセスの制約される環境でも利 用可能である.また, 原理的には極低温から約 $1300^{\circ} \mathrm{C}$ まであらゆる作動流体に適用できる特徵を持つため, エ ンジン筒内ガスの温度・速度同時計測に限らず, 蒸気タービン内の流動など従来手法では困難であった高温環境 場での温度・速度可視化計測を実現できる可能性がある.

一方で，オイル流れなど簡易的な流れを対象とした測定と異なり，エンジン筒内の高温ガス流れを測定するこ とは必ずしも容易ではない，本報ではまず，無機蛍光体を可視化エンジン内壁に塗布し，高速度カメラを用いて 寿命法で壁面温度分布を測定する. 更に，無機蛍光体を可視化エンジン内にシーディングし，PIV と燐光寿命法 による温度計測法を組み合わせた温度場・速度場の同時計測法を用いて, エンジン筒内ガスの二次元温度・速度 情報を可視化したので報告する.

\section{2. 燐光寿命温度計測法}

\section{$2 \cdot 1$ 無機蛍光体}

蛍光体を用いた高温場での温度計測では，使用する蛍光体により発光強度やスペクトル・減衰率・感度の高い 温度範囲など, 燐光特性が大きく異なるため, 事前に燐光特性を把握して適切な蛍光体を選定する必要がある. そこで, 励起光源として YAG 第 3 高調波(Esi Ltd., Tempest UV, 355nm, 最大 40mJ/pulse)のパルスレーザーを用い, 複数の蛍光体の燐光特性を調査した. その結果, 高温条件でも温度依存性を示し, かつ, 比較的安価で汎用的に 利用できる蛍光体として, $\mathrm{La}_{2} \mathrm{O}_{2} \mathrm{~S}: \mathrm{Eu}$ (以下, LOS), $3.5 \mathrm{MgO} \cdot 0.5 \mathrm{MgF}_{2} \cdot \mathrm{GeO}_{2}: \mathrm{Mn}^{4+}$ (以下, MFG)を選定した.

熱電対によるこれまでの試験測定の結果から予想されるエンジン筒内壁面温度は $200^{\circ} \mathrm{C}$ 以下であるため，この 条件で温度感度が高く, 発光強度の大きい LOS を壁面温度計測に用いることとした. また, 筒内ガス温度・速度 
同時計測には 200 $800^{\circ} \mathrm{C}$ の広い範囲で温度依存性を示し，高温条件でも比較的発光強度が大きく画像撮影に有利 と考えられる MFG を用いた。

例として図 1 に，120 240 ${ }^{\circ} \mathrm{C}$ の範囲における LOS の燐光強度の時間変化を示した．実験では LOS 蛍光体と熱 電対をヒーターに固定し, 加熱して一定温度に保った後にパルスレーザーで励起し, 燐光強度をピンフォトダイ オードとオシロスコープ及び高速度カメラを用いて測定した．横軸に時間を示し，励起の瞬間の時刻を $0 \mu \mathrm{s}$ とし た. 励起光強度がパルスごとに若干変化するため, 縦軸は各条件での燐光強度最大值で規格化した相対輝度值を 示している．ここで燐光強度が $1 / \mathrm{e}$ に減衰するまでに要する時間を燐光寿命と定義する．図 1 より，LOS では温

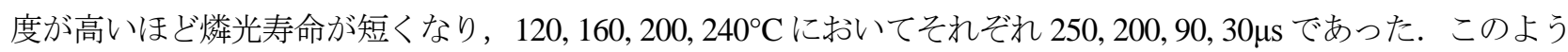
に，選定した蛍光体の燐光強度の時間変化率(燐光寿命)は温度依存性を有する.

蛍光体燐光寿命は蛍光体の量や励起光強度に依存しないはずであるが，確認のため寿命のレーザー励起強度に 対する依存性をフォトダイオードで調べた結果，2 40mJ/pulse の条件で，依存性は見られなかった。

本実験では条件により, 筒内の圧力や酸素分圧が変化する. Feist $ら^{(19)}$, Brubach ら ${ }^{(20)}$ は LOS, YAG:Dy, MFG, $\mathrm{Y}_{2} \mathrm{O}_{3}: \mathrm{Eu}$ といった無機蛍光体の燐光に与えるガス成分や圧力の影響について報告しており，LOS, YAG:Dy, MFG の燐光寿命は酸素濃度, 圧力依存性を全く示さず, $\mathrm{Y}_{2} \mathrm{O}_{3}$ : $\mathrm{Eu}$ の燐光寿命は酸素濃度の影響を受けることを明らか

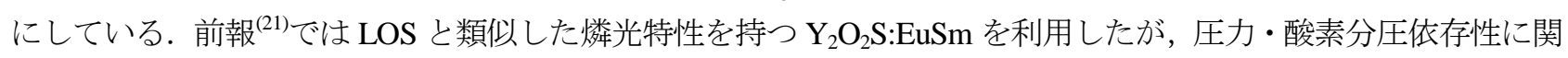
する報告例がないため，本研究では LOS を用いた。

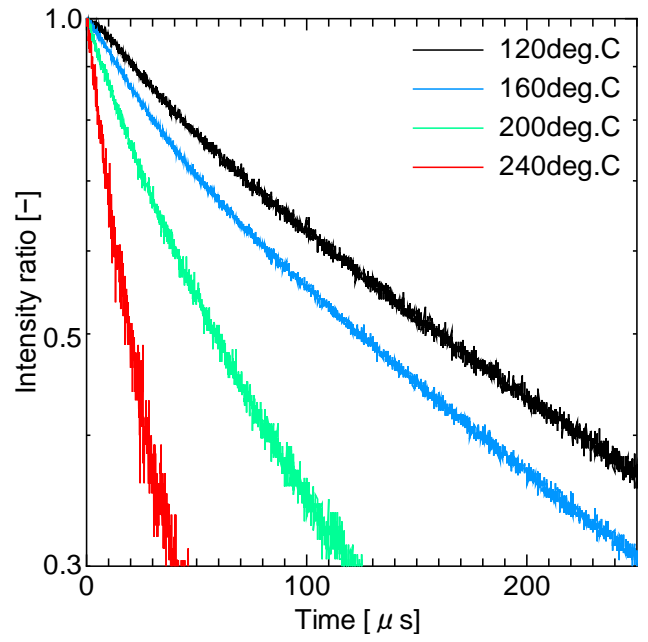

Fig. 1 A decay of normalized luminescent intensity of LOS

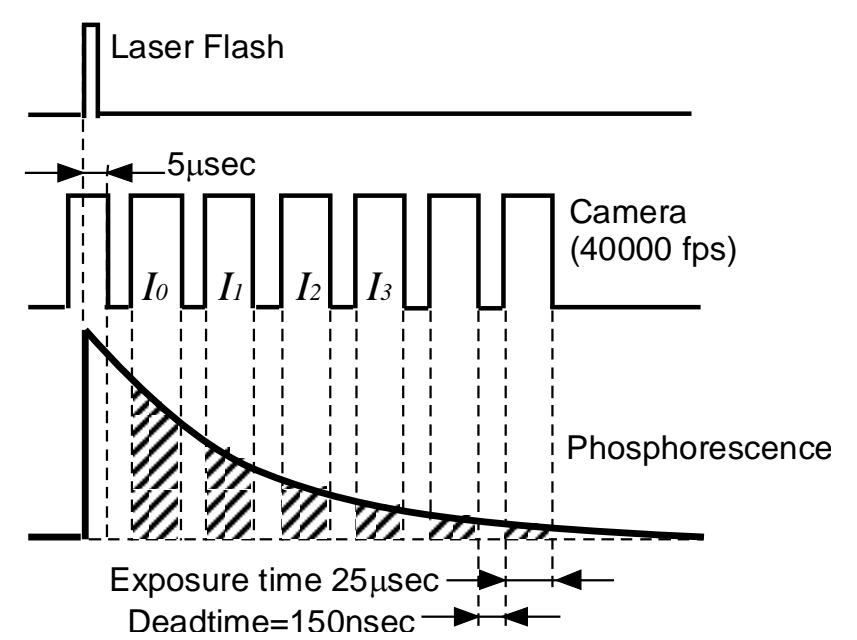

Fig.2 A timing diagram of imaging using a high-speed camera

\section{$2 \cdot 2$ 燐光寿命測定方法}

高速度カメラを用いた寿命法による温度計測法の概要について述べる．撮影のタイミングチャートを図 2 に示 した. 高速度カメラ(Photron Ltd., Fastcam S.A.1.1)を 40000 frame per second (fps) で動作させ，電子シャッターは用 いず, 各フレームの露光時間を約 $25 \mu \mathrm{s}$ とした. フレーム間の撮影デッドタイムは約 $150 \mathrm{~ns}$ である. 画像は $512 \mathrm{x} 256$

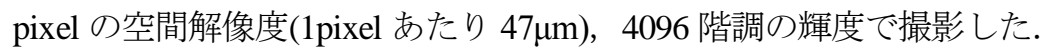

蛍光体を励起する $20 \mu \mathrm{s}$ 前から連続して数枚の画像を撮影した. 励起の瞬間を含む 1 枚目の画像は励起光の散乱 や他の物質からの蛍光等のノイズを含むため, 以降の解析では一切用いない. つまり図 2 中に斜線で示した, 励

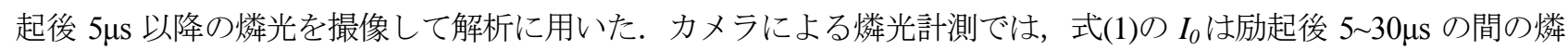
光を撮影した画像輝度である. また, 今回対象とした可視化エンジンでは約 $110 \mu \mathrm{s}$ でクランク角(Crank Angle Degree: CAD)が 1 度変化するなど, 筒内ガスの状態変化が速い. そこでクランク角 1 度以内の時間分解能を達成 するため, 本論文中の測定では全ての実験で $I_{0}$ から $I_{3}$ の 4 枚の画像を 1 セットとして燐光寿命を求めた.

燐光寿命を表す近似式には，一般的に指数関数が用いられるが，燐光は複数の発光プロセスを持つために，必 ずしも簡単な関数とはならない(22) (24). 一方, 燐光寿命をできるだけ詳細・的確に近似することが, 温度解析の精 度に大きく影響する. 本研究では燐光寿命を燐光強度が $1 / \mathrm{e}$ になる時間とし, 燐光の減衰が単純な一次指数関数 で表されると仮定する. 同時に, 測定值をより良く近似するために定数係数 $C$ を付加し, 式(1)で燐光の減衰を評 
価し, 燐光寿命(減衰係数) $\tau$ を求めた. $C$ は 0.98 1.01 の值であった. ここで $I$ はある時刻 $(t)$ にンサが感じる総燐 光強度， $I_{0}$ は基準時刻における燐光強度である.

$$
I / I_{0}=C \cdot e^{-t / \tau}
$$

励起光強度, 蛍光体濃度, ターゲットからセンサ素子までの光学パスなどがセンサの各ピクセルによって異な るため，燐光強度はピクセル位置によって異なる．減衰係数を利用する寿命法では理想的には， $I_{0}$ で除して算出 される相対輝度の減衰を利用寸ることにより, 蛍光体濃度の非均一性, 励起光強度の時間・空間的な非一様性に よる影響を排除できる. しかし高速度カメラの CMOS センサの各ピクセルの光量に対する応答は必ずしも線型で はなく，また，この非線形性はピクセルごとに異なる。この非線形性やセンサノイズは減衰係数の算出結果に影 響を与え得る．これらピクセルごとの誤差を低減するため, 本研究では, 撮影した燐光輝度を 16×16 pixels の領 域に区切り, 各領域を $50 \%$ ずつオーバーラップさせて輝度の平均值を算出し, $8 \times 8$ pixels の空間解像度で燐光寿 命 $\tau$ を求めた.

壁面温度計測では蛍光体をセラミックバインダに混合して壁面に塗布した．蛍光体を含まずセラミックバイン ダのみを塗布した面にレーザーを照射した場合, カメラ及びフォトダイオードで検出可能な燐光は生じなかった.

校正実験では, 温度を $10^{\circ} \mathrm{C}$ ずつ変化させながら温度一様場の燐光減衰を撮影し, 各条件での燐光寿命を求め た. 次に，温度と燐光寿命の関係を適切な校正関数で近似する. なお，燐光物質は複雑な燐光放出プロセスを持 つため, 校正関数の形を理論的に与えることは容易ではなく, 本計測手法では校正データを最もよく近似する実 験式を用いて, カメラで求めた燐光寿命と温度を関係づける. 本論文では三次式を用いた。 これにより，未知の 温度場の計測が可能となる.

\section{$2 \cdot 3$ エンジン諸元および運転条件}

エンジン主要諸元を表 1 に, 単気筒可視化エンジン外観を図 3 に示寸，ボア $86 \mathrm{~mm}$ ，ストローク $86 \mathrm{~mm}$ で圧縮 比は 8.1 である. 吸排気それぞれ 2 つのバルブを備える. 燃焼室内を可視化できるようにエンジンヘッドに石英 製サイドウィンドウを設置している．ヘッド，ブロックの間に伸長スリーブ，伸長ピストンを設置し，石英製ピ ストンウィンドウと $45^{\circ}$ アルミ蒸着ミラーにより燃焼室下側からの可視化も可能である. 実験ではクランク角 $1^{\circ}$ ごとにエンジン内筒内の圧力を測定した．また，クランク角を分解能 10 で測定できるエンコーダーを用いてエン ジン, 光源とカメラを同期し, これらをエンジン回転数にあわせて $12.5 \mathrm{~Hz}$ で動作させた.

Table 1 Engine specification

\begin{tabular}{|c|c|c|}
\hline Engine & \multicolumn{2}{|c|}{ Optical single cylinder } \\
\hline Bore $\times$ Stroke & \multicolumn{2}{|c|}{$86 \mathrm{~mm} \times 86 \mathrm{~mm}$} \\
\hline Displacement volume & \multicolumn{2}{|l|}{$500 \mathrm{cc}$} \\
\hline Compression ratio & \multicolumn{2}{|l|}{8.1} \\
\hline Steady tumble ratio & \multicolumn{2}{|l|}{0.59} \\
\hline \multirow{4}{*}{ Valve timing at $1 \mathrm{~mm}$ lift } & Ex open & $31^{\circ} \mathrm{BBDC}$ \\
\hline & Ex close & $-31^{\circ}$ ATDC \\
\hline & In open & $-12^{\circ} \mathrm{BTDC}$ \\
\hline & In close & $17^{\circ} \mathrm{ABDC}$ \\
\hline
\end{tabular}

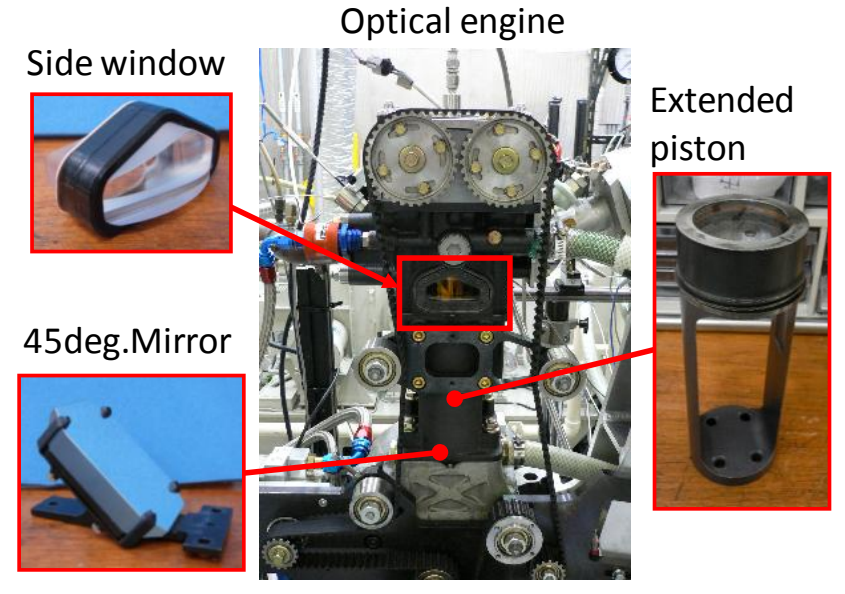

Fig.3 Pictures of an optical engine

\section{3. エンジン筒内壁面瞬時温度計測}

\section{$3 \cdot 1$ 実験装置}

本研究ではまずエンジン筒内の壁面温度計測を行った．図 4 に実験装置を示す．石英製サイドウィンドウに対 して反対側のエンジンヘッド壁面に直径 $24 \mathrm{~mm}$ のアルミ製ターゲットブロックを取り付け，その表面に接着剤を 
バインダーとして蛍光体を塗布した。蛍光体塗膜の背面へ $\mathrm{K}$ 熱電対(直径 $1.1 \mathrm{~mm}$ )を挿入し，モニター用として温 度を同時に計測した。エンジン前側の石英製サイドウィンドウから拡散板により広げられたレーザーをターゲッ トブロック全体に当たるように照射し，同じ方向から高速度カメラで橉光を撮影した. カメラレンズ前には光学 フィルタ(シグマ光機製 SCF-37L)を設置し, 励起光を遮断した。

\section{Upperview Side view}

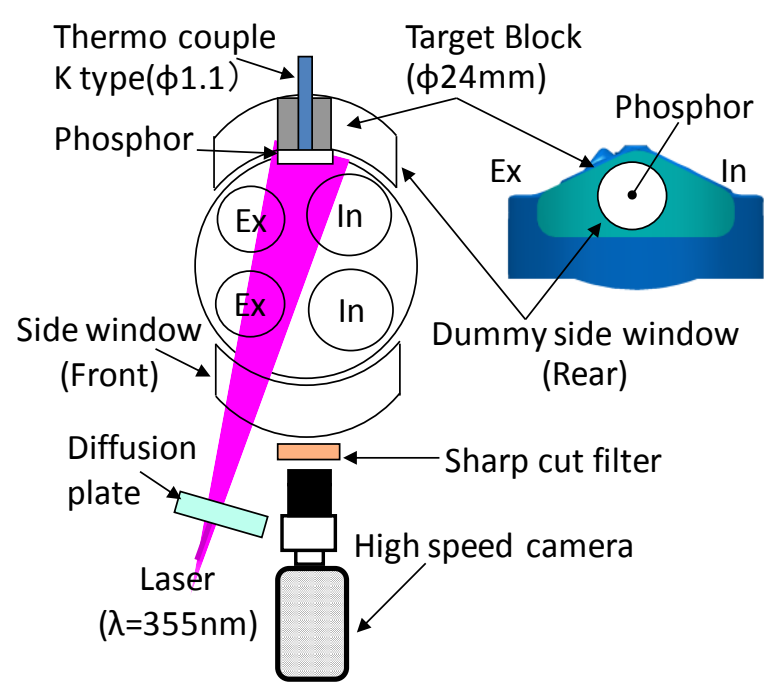

Fig.4 A schematics of experimental apparatus for a wall-temperature measurement

\section{$3 \cdot 2$ 温度校正}

本研究では励起直後の燐光強度分布を高速度カメラで撮影し, 各部位の燐光強度の時間変化から燐光寿命を求 めて温度を評価する. そこでまずエンジンを停止し，カートリッジヒータを用いて LOS を塗布したアルミニウム ターゲット表面の温度を一様にして大気圧条件下で校正実験を行った．結果を図 5 に実線で示した．横軸は温度

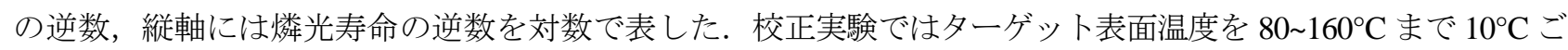
とに変化させた．表面温度は $\mathrm{K}$ 熱電対でモニターし，各条件で温度を 10 分間ほど安定させてから撮影した。レ ーザー(Spectra-Physics, Pro290, 120mJ/pulse)を 12.5Hz で発振し, 各温度条件で 300 セットのデータを取得した. 燐光寿命の算出及び燐光寿命と温度の関係式の算出には，この 300 セットの平均を利用した．以下，ターゲット をエンジンに設置して行った，この校正を「その場校正」と呼ぶ.

また, エンジン実験の事前に, ステンレス板に塗布した LOS とヒーターを用い, 表面温度を $80 \sim 240^{\circ} \mathrm{C}$ まて $10^{\circ} \mathrm{C}$ ごとに変化させ，ダイオード(白丸)およびカメラ(黒角)を用いて校正データを取得した．以下，事前に実験室で行 った，この校正を「外校正」と呼ぶ. ピンフォトダイオードとオシロスコープを用いて $10 \mathrm{MHz}$ で取得したデー 夕は，比較のため，カメラの露光時間に相当する時間のデータを積分して，燐光寿命を算出した．これらの結果 も図 5 に示した. 図 5 の校正データの標準偏差はいずれも $1 \%$ 以下と小さかった. 図 5 より, 校正法に関わらず 低温側では LOS の燐光寿命の温度に対する変化率が小さいため, 校正関数のわずかな誤差も比較的大きな温 度評価誤差につながり易い. なお，カメラの設定は「その場校正」と「外校正」とで共通である.

2.2 節燐光寿命測定法でも述べたように, 高速度カメラのCMOS センサ特性により, 寿命法においてもピ クセル位置による温度算出誤差が生じ得る. また, 励起された蛍光体は接着剤成分にもエネルギーを与えな がら基底状態にもどるため，場所による接着剤濃度の不均一性も，燐光寿命の算出結果に影響を与え得る.

より正確な温度計測を行うためには, 計測系を瞬時温度場計測実験と同じ条件にしたその場校正を行い, 画像の微小エリア毎に燐光寿命を校正・算出する必要がある. 一方, 実験工程数の観点からは，常に共通の 校正データを適用できる外校正のほうが好ましい.つまり，外校正データでは校正時とエンジン筒内実験時 とで異なるサンプルの異なる部位を見ている，そこで外校正では，温度一様場では燐光寿命はどの領域をと っても一様であると仮定し, 温度と燐光寿命との関係式が画像全領域で共通であるとして扱う。外校正では 場所によるピクセルごとの非線形性や接着剤濃度の不均一性を考慮しない. 

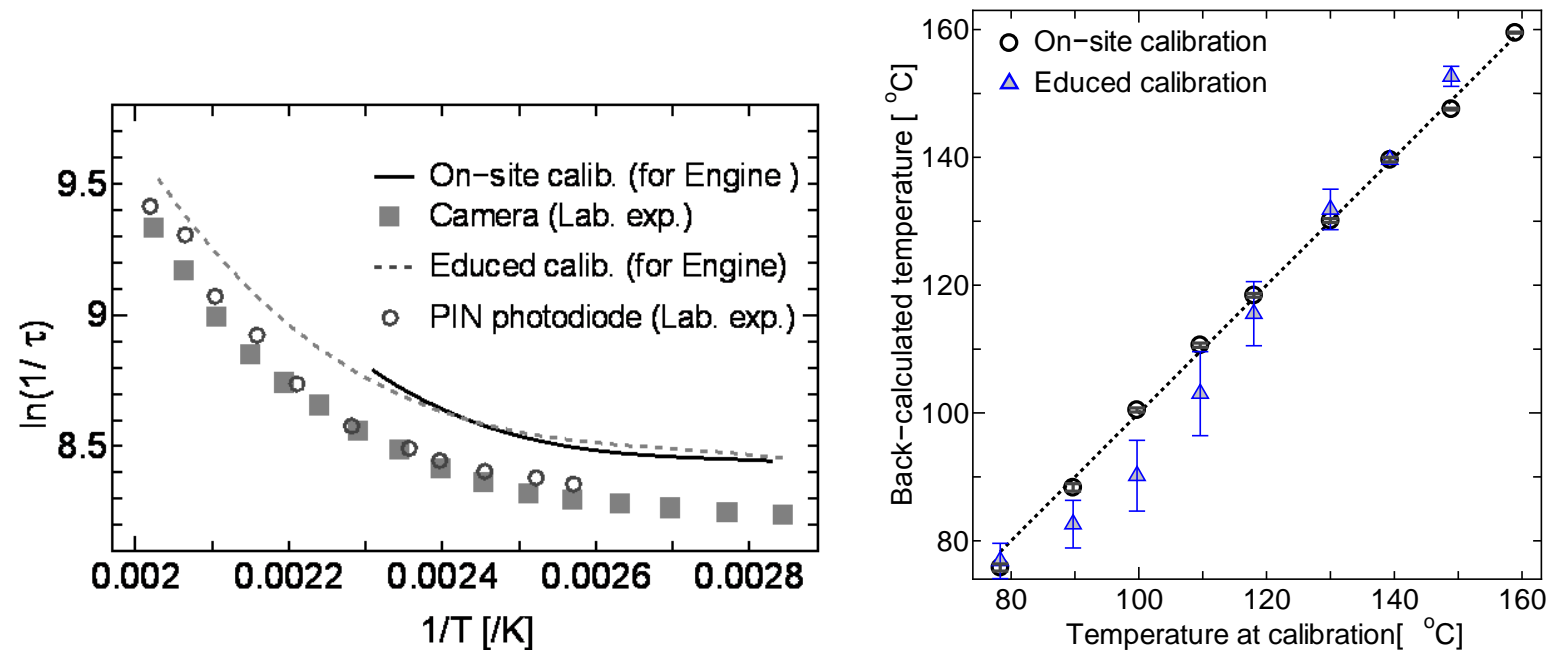

Fig.5 A relation between temperature and lifetime of LOS

Fig.6 Uncertainties of the wall-temperature measurement

図 5 より, 実験室で取得したダイオード(白丸)とカメラ(黒角)による二種類の外校正データは互いに良く一致し た. また，その場校正で得た燐光寿命と温度との関係は，外校正結果を平行移動して描いた図 5 中の点線と 比較的良く一致した。 その場校正と外校正の差異が生じた理由は現時点では明確にできていないが，ここで はある一条件におけるその場校正結果を参照点として，外校正結果を平行移動した点線の減衰曲線を外校正 関数として利用した.

計測精度の検討は，その場校正の校正関数を算出するために取得した既知の一様温度場 $\left(80 \sim 160^{\circ} \mathrm{C}\right)$ におけ る 300 セットの画像を利用して行った。画像中心の 16×16 pixels の領域で算出した温度の 300 セットでの平均 及び標準偏差を図 6 にまとめた。 その場校正関数を用いて温度を評価した結果，80 160 $\mathrm{C}$ の全範囲を通じ， 既知の值との差は最大で-2.47 1.02 ${ }^{\circ} \mathrm{C}$ となった。同じ画像を外校正関数を用いて評価した結果，80 160 ${ }^{\circ} \mathrm{C} の$ 範囲を通じて，既知の值との差は-9.51 7.10 C となり，その場校正よりも差が大きかった. 図 6 より，300セ ツトの画像から算出した值の標準偏差は，その場校正では小さく，外校正では変差も大きくなった。この誤 差は, 熱電対で測定した温度と画像中心での温度の差異と, 画像から燐光寿命を算出して寿命と温度の関係 を求めるプロセスに起因して生じている.

また，16×16 pixels ごとに算出した温度の画像全体における空間的なばらつきも求めた。その場校正では，画 像全域における空間標準偏差も最大 $0.37^{\circ} \mathrm{C}$ と小さく，高い精度で温度を算出できた。外校正では，画像全域 を通じての空間標準偏差も最大 $3.84^{\circ} \mathrm{C}$ とり, その場校正の結果よりも大きかった.これは前述したように, 外校正では場所によるピクセル非線形性や接着剤濃度の不均一性を考慮していないためである.より正確な 温度計測のためには，その場校正による校正関数算出が必要である.

Table 2 Comparison with previous researches

\begin{tabular}{|c|c|c|c|c|}
\hline Ref. No. & Phosphor & Frame rate(n) & Time & Error \\
\hline On-site Calibration & LOS & $40 \mathrm{k} \mathrm{fps}(4)$ & $100 \mu \mathrm{s}$ & $-2.47 \sim 1.02^{\circ} \mathrm{C}$ \\
\hline Educed calibration & LOS & $40 \mathrm{k} \mathrm{fps}(4)$ & $100 \mu \mathrm{s}$ & $-9.51 \sim 7.10^{\circ} \mathrm{C}$ \\
\hline$(21)$ & $\mathrm{Y}_{2} \mathrm{O}_{2} \mathrm{~S}: E u S m$ & $40 \mathrm{k} \mathrm{fps}(\sim 10)$ & $250 \mu \mathrm{s}$ & $-2.25 \sim 1.15^{\circ} \mathrm{C}$ \\
\hline$(12)$ & $\mathrm{MFG}$ & $150 \mathrm{k} \mathrm{fps}(15000)$ & $100 \mathrm{~ms}$ & $\pm 1 \sim 5.5^{\circ} \mathrm{C}$ \\
\hline$(13)$ & $\mathrm{MFG}$ & $10 \mathrm{k} \mathrm{fps}(8)$ & $1.3 \mathrm{~ms}$ & $\pm 1 \sim 5^{\circ} \mathrm{C}$ \\
\hline$(14)$ & $\mathrm{Y}_{2} \mathrm{O}_{3}: \mathrm{Eu}$ & $1000 \mathrm{k} \mathrm{fps}(100)$ & $100 \mu \mathrm{s}$ & $\pm 80^{\circ} \mathrm{C}$ \\
\hline
\end{tabular}

近年の類似研究と計測精度の比較を行い，蛍光体種類，撮影速度と温度算出に利用する画像枚数(n), 測定 時間，温度測定の不確かさを表 2 にまとめた. 利用した蛍光体はそれぞれ異なるが，本研究のその場校正を 
用いた算出結果は, クランク角 $1^{\circ}$ の時間分解能 $(100 \mu \mathrm{s})$ で, すなわち 4 枚と少ない画像枚数・画像処理負荷で,

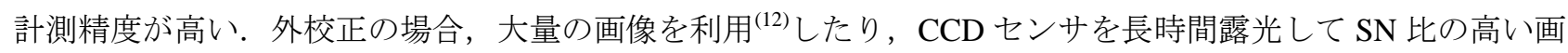
像を利用 ${ }^{(13)} し た$ 他研究の精度が良い.ただしこれらは本研究より測定時間が 10 1000 倍長く, エンジン筒内 温度計測には時間分解能が不十分である。

\section{$3 \cdot 3$ エンジン筒内温度測定結果}

エンジン回転数 $N e[\mathrm{rpm}]=1500$ とし, スロットル開度を変化させて実験を行った. 吸入空気量は負圧開閉式のス ロットルで調整し，大気圧に対する吸気管内相対圧力 $P_{\text {intake }}$ をモニターし，スロットル全閉状態 $P_{\text {intake }}=-62 \mathrm{kPa}$ ，ス ロットル全開状態 $P_{\text {intake }}=0 \mathrm{kPa} の 2$ 種類とした. スロットル全開(WOT)時の体積効率は $72 \%$ で, 全閉時の体積効率 は 10\%であった. また，レーザー及びカメラを同期させるクランク角を変化させて粼光画像を取得した.

その場校正を用いてモータリング運転時の壁面温度を解析した結果を図 7 に示した. 横軸をクランク角, 縦

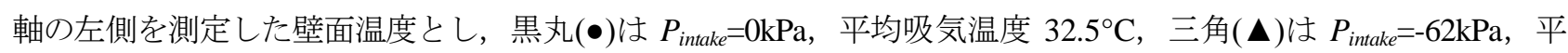
均吸気温度 $52.8^{\circ} \mathrm{C}$ の条件における温度測定結果である.これらの測定值のサイクル標準偏差は全条件を通じ

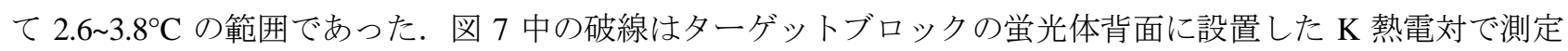
したサイクル平均温度を示す. $P_{\text {intake }}=0 \mathrm{kPa},-62 \mathrm{kPa}$ の場合の測定結果はそれぞれ $101.7^{\circ} \mathrm{C}$ (黒い破線), $97.4^{\circ} \mathrm{C}($ 灰 色の破線)であった。 また, 図 7 には筒内圧から断熱圧縮を仮定して計算したガス温度 $T_{\text {gas ad }}$ を点線で示した. ガス温度 $T_{\text {gas } a d}$ のみ, 図の右側縦軸を参照している.

筒内圧からガス温度を計算する場合, 初期温度は吸気管内に設置された熱電対の温度 $T_{\text {gas_intake }}$ とし, 比熱比は 筒内圧力と容積の変化からポリトロープ指数を求め, それを平均比熱比 $\kappa_{\text {ave }}$ として式(2)より求めた. ここで, $P$ は筒内圧， $P_{I V C}$ は吸気バルブが閉じる時期の筒内圧である. $T_{g a s}$ ad は吸気バルブが閉じて，排気バルブが開くまで 計算を行った.

$$
T_{\text {gas_ad }}=T_{\text {gas_intake }}\left(P / P_{I V C}\right)^{\left(\frac{\kappa_{a v v}-1}{\kappa_{\text {ave }}}\right)}
$$

図 7 の黒丸に注目すると, 吸気行程であるクランク角 $\theta=-300 \sim-120$ deg.ATDC では徐々に壁面温度が低下し ている.これは筒内に吸入された新規空気により壁面が冷却されたためと考えられる. 約-90deg. ATDC を過ぎ て圧縮行程に入った後, 膨張行程前半(30deg. ATDC)まで温度が上がっている. ピストンによる断熱圧縮により ガス温度が増加し，やや時間遅れをもって壁面温度が上昇したためである．また，30 60deg.ATDC の間には再 び温度が低下し始めている. 温度変化の時間応答はクランク回転による $T_{g a s}$ ad に対応して変化しており, 少 なくとも $30 \mathrm{deg}$. 以内に応答していることが確認できた．ただし $T_{\text {gas_ad }}$ は $T_{\text {gas_intake }}$ や $P_{I V C}$ に依存するガス温度推 定值であり，壁面温度の測定値と直接比較できるものではない.

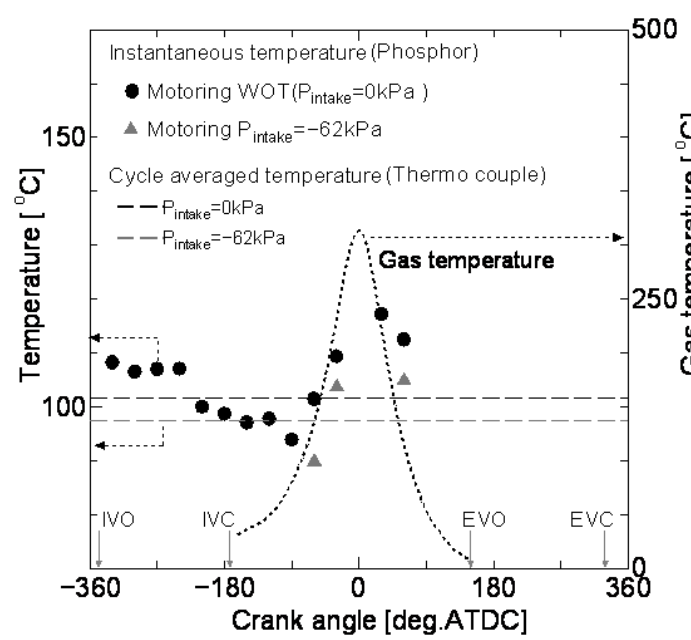

Fig.7 Measured temperatures in the engine

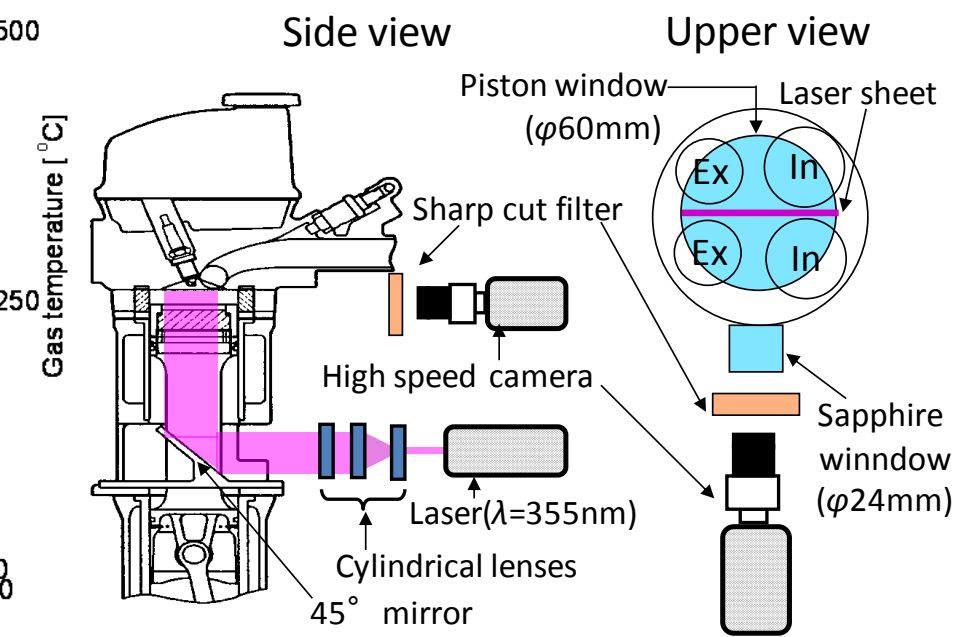

Fig.8 Experimental setup for the combined measurement 
測定した壁面温度は熱電対によるサイクル平均温度とほぼ等しく，良い精度で計測できていることが分かる． 運転条件による違いについて見てみると，スロットルを絞ることにより壁面温度が下がっている．空気流入 量が減り, ガス流速及び筒内圧力が低下し, 熱伝達係数が減少したためと考えられる. スロットル全開の場合, 熱電対によるサイクル平均温度は $101.7^{\circ} \mathrm{C}, P_{\text {intake }}=-62 \mathrm{kPa}$ では $97.4^{\circ} \mathrm{C}$ で差は $4.3^{\circ} \mathrm{C}$ であった. $\theta=-30,60 \mathrm{deg} . \mathrm{ATDC}$ における蛍光体による測定結果は WOT の場合に $109.4^{\circ} \mathrm{C}, 112.5^{\circ} \mathrm{C}, P_{\text {intake }}=-62 \mathrm{kPa}$ では $103.7^{\circ} \mathrm{C}, 104.9^{\circ} \mathrm{C}$ であり, 各クランク角における差は $5.7^{\circ} \mathrm{C}, 7.6^{\circ} \mathrm{C}$ であった。 これはスロットル開度による平均温度差 $4.3^{\circ} \mathrm{C}$ にほぼ等 しく，本手法によって妥当な瞬時温度を算出寸ることができたと考えられる.

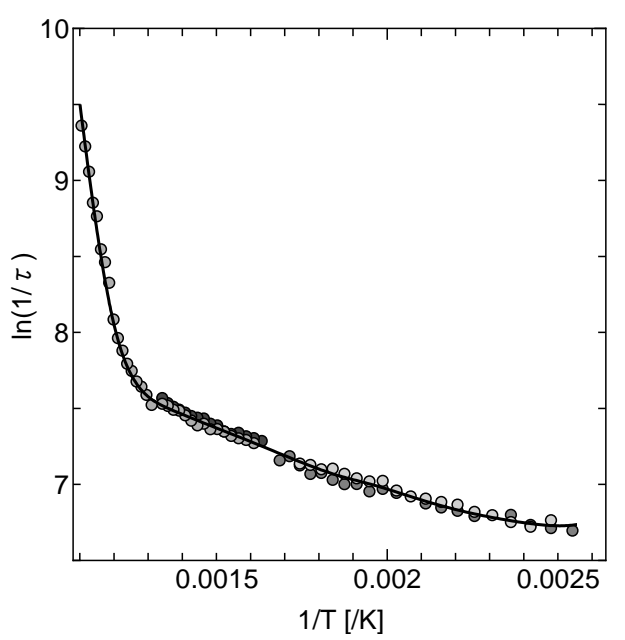

Fig.9 A relation between temperature and lifetime of MFG

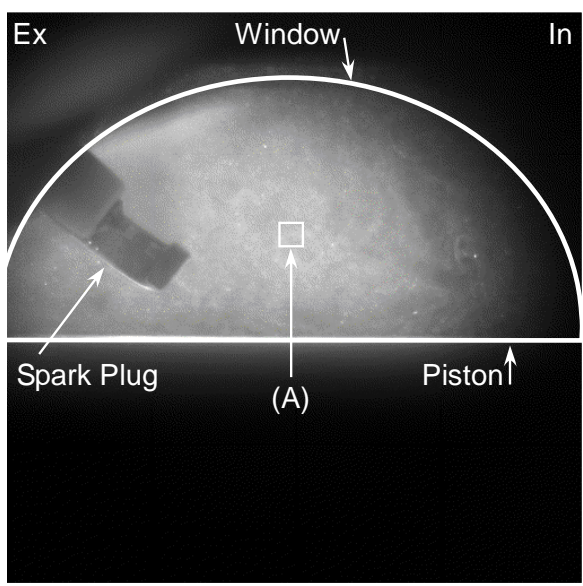

Fig.10 An example of captured images

\section{4. ガス温度 · 速度分布同時計測}

\section{$4 \cdot 1$ 実験装置}

エンジン筒内の速度計測例 ${ }^{(25)}$ は少なくない。 また，感温液晶を用いた液体中の温度速度同時計測例 ${ }^{(26,27)}$ みら れる. しかし, エンジン筒内などガス流れの温度速度計測例はないため, 本研究ではエンジン筒内のガス流れを 対象にこれを試みる.

実験装置の概要を図 8 に示した。 図 8 はエンジン筒内ガス流れの垂直断面を測定した際の様子を示してい る.レーザー光をシリンドリカルレンズにより幅 $100 \mathrm{~mm}$, 厚さ $1 \mathrm{~mm}$ のシート状にした後, $45^{\circ}$ ミラーと石英製ピ ストントップを通過させ, 筒内へ照射した. 計測位置は垂直断面のボアセンターである. エンジン前方に取り付 けたサファイア製ウィンドウ $(\varphi 24 \mathrm{~mm})$ を通して高速度カメラで燐光を撮影する. なお，水平断面を撮影する場合 は, 図 8 のレーザーの位置にカメラを置き, 図 8 のカメラの位置から水平にレーザーシートを入射する.

ここではガス温度・速度計測のトレーサーとして MFG を用いる．無機蛍光体はやや凝集性が高く, シーデ イングには困難を伴う. そのため, MFG 粒子に二酸化ケイ素 $\left(\mathrm{SiO}_{2}\right)$ を $3 \mathrm{~nm}$ 程度の厚さでコーティングして凝集性 を抑えた粒子を用いる. 実験では $\mathrm{SiO}_{2}$ ナノコート $\mathrm{MFG}$ 粒子をスロットル後流の吸気管から筒内一吸入させた.

$\mathrm{SiO}_{2}$ ナノコート MFG 粒子を金属板表面に固定し，2・1 2 節と同じ手順で粒子の燐光寿命と温度との関係を事 前に求め, まとめた結果を図 9 に示した. $\mathrm{SiO}_{2}$ ナノコート $\mathrm{MFG}$ 粒子の燐光寿命は $500^{\circ} \mathrm{C}$ 以上の温度で特に強い 温度依存性を示した. 同じ温度条件下で 10 回続けて寿命を測定した際の標準偏差は, いずれの温度でも $1 \%$ 以下で あり, 異なるサンプルで測定した場合のばらつきは最大 $\pm 10^{\circ} \mathrm{C}$ であった. ガス温度を一様かつ安定に保ちながらそ の場校正データを得ることが難しいため，ガス温度速度同時計測では，この外校正データを用いて以降の温 度評価を行う。

\section{$4 \cdot 2$ ガス温度 $\cdot$ 速度分布同時計測}

実験では回転数やスロットル開度などのエンジン運転条件を変化させ，エンジン筒内ガス温度・速度の同 時計測を行った．筒内で撮影した燐光画像の例を図 10 に示す. PIV 解析が可能な粒子画像を取得できている. 
図 10 はピストンが上死点に達した瞬間(Odeg.ATDC)の画像で, このときのエンジン運転条件は $N e=700 \mathrm{rpm}$, モー タリング, $P_{\text {intake }}=-62 \mathrm{kPa}$ である. 図左側の突起は点火プラグで, 図中の白い半円は可視化用サファイア空の位 置を示している.また，このとき燐光減衰中に撮影した連続する 2 時刻の画像間における粒子移動量は 1〜2pixel ほどであり，PIV 解析も可能である. 温度速度とも連続する 4 時刻の画像を用いて算出した. 得られた瞬時速度 分布及び瞬時温度分布を図 11 に示した. 速度分布の背景には撮影した画像の例を示している. また，ベクトルの 長さは速度を表し，図右上部に基準となるべクトルを示した．温度分布図では黒から白になるにつれて温度が高 い.ここではタンブル流(縦旋回流)が生じていることがわかる．エンジン運転条件がモータリングであったた め温度分布はほとんど見られず，ほぼ均一な温度であった。
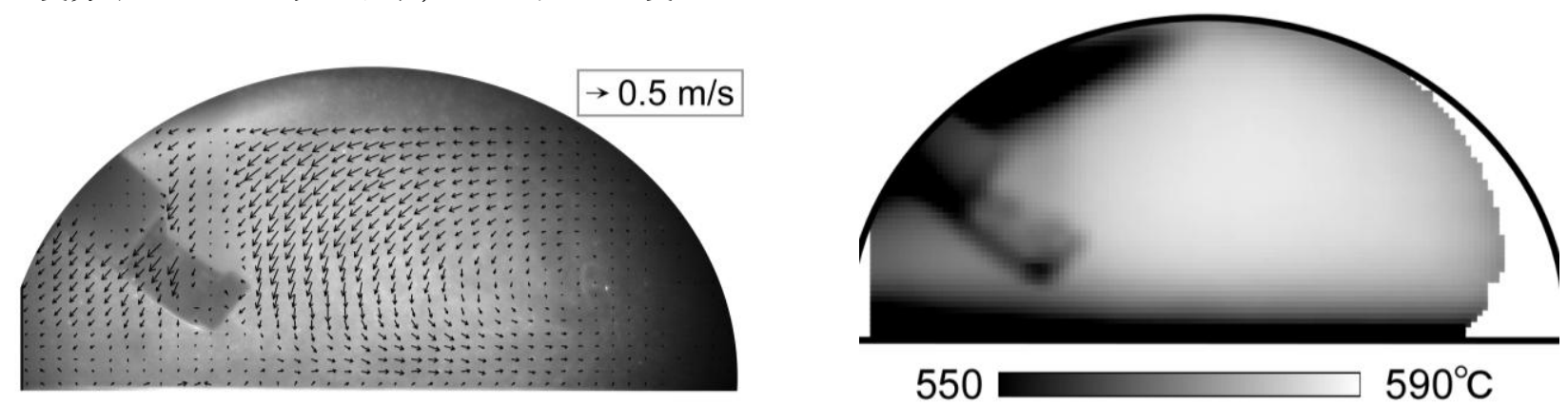

Fig. 11 Gas temperature and velocity field (Ne=700rpm, $P_{\text {intake }}=-62 \mathrm{kPa}, 0 \mathrm{deg}$. ATDC $)$
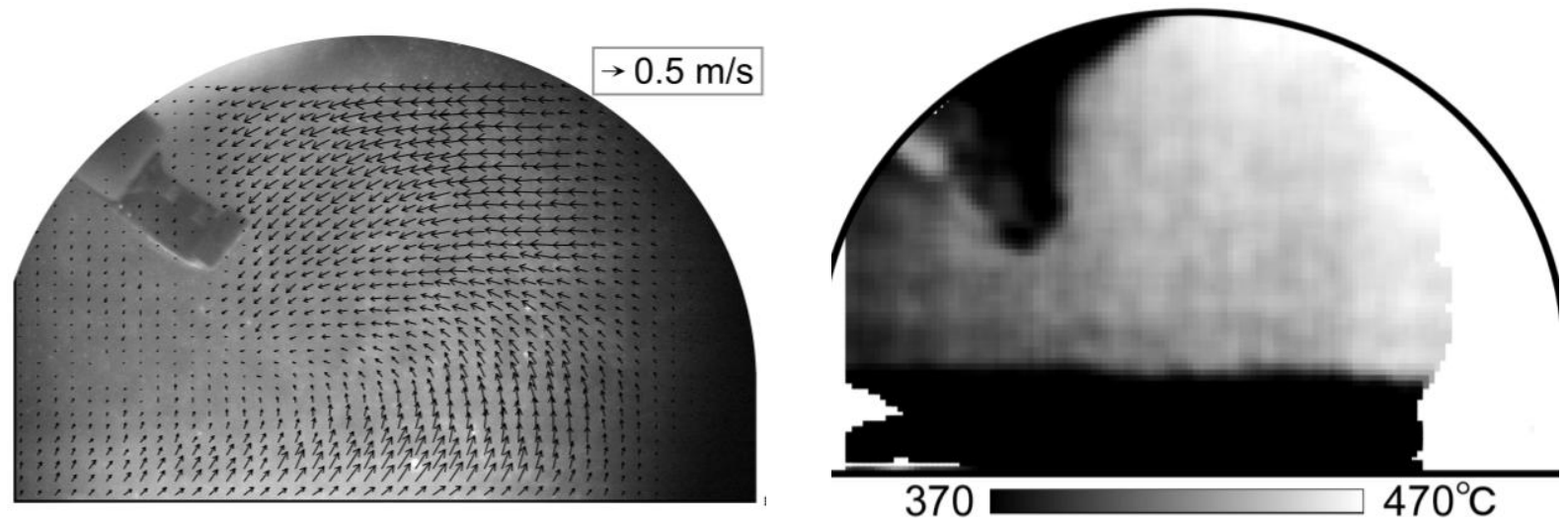

Fig. 12 Gas temperature and velocity field $\left(N e=700 \mathrm{rpm}, P_{\text {intake }}=-62 \mathrm{kPa},-30 \mathrm{deg} . \mathrm{ATDC}\right)$
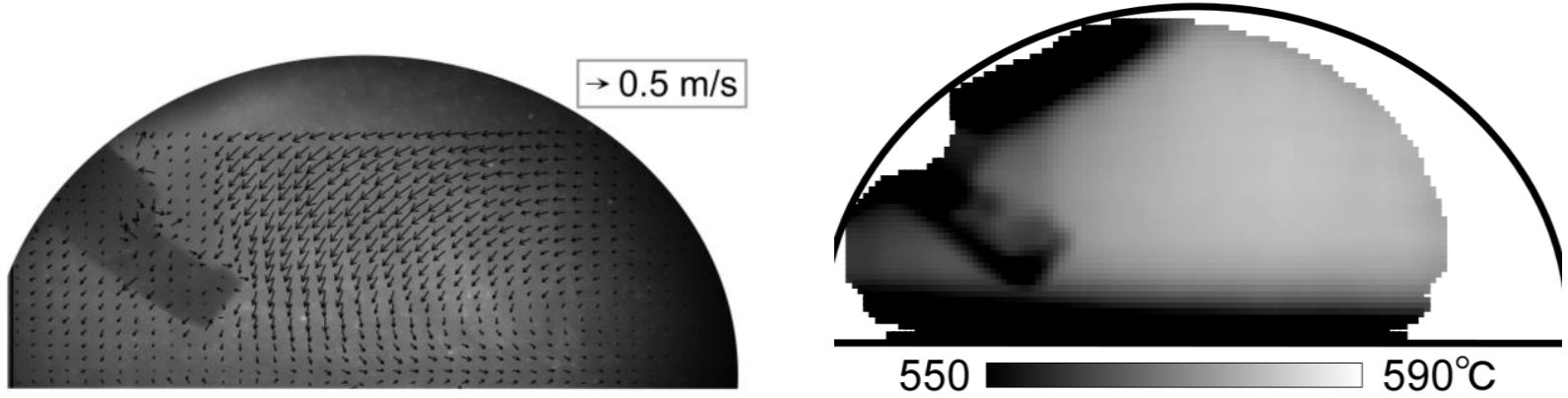

Fig. 13 Gas temperature and velocity field $\left(N e=700 \mathrm{rpm}, P_{\text {intake }}=-40 \mathrm{kPa}, 0 \mathrm{deg} . \mathrm{ATDC}\right)$

図 12 は $N e=700 \mathrm{rpm}, P_{\text {intake }}=-62 \mathrm{kPa}$ でクランク角-30deg.ATDC における測定結果である. 速度分布では, $\theta=-30 \mathrm{deg} . A T D C$ で吸気側から排気側へ燃焼室上面を沿って流れるタンブル流とピストントップ付近に上昇流が見 られる. 速度は約 $0.8 \mathrm{~m} / \mathrm{s}$ である. 流速は Odeg.ATDC の場合よりやや大きく, 渦の中心は Odeg.ATDCでは吸気バ ルブ側であったが，-30deg.ATDC では筒内中央側で大きな旋回渦を形成していることがわかる．また， -30deg.ATDC ではピストントップ付近に上昇流が見られる. 温度分布については, $\theta=-30 \mathrm{deg}$.ATDC から 0deg.ATDC になるとピストンによる断熱圧縮によりガス温度が図中心部で $135^{\circ} \mathrm{C}$ 増加している. なお，図 12 では点火プラ グ，またはピストントップ付近の温度が他に比べて低く計測されている．これは，励起光が弱く，画像輝度が低 かったためや，構造物に付着した燐光の影響によるものである. 


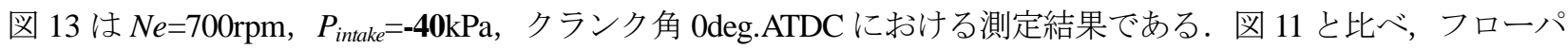
ターンは類似しているが, 多くの空気を吸入しているため流入初期流速が速く, 図 13 の瞬間においても全体的に 図 11 より速い. 温度は図 11 と比べ, 画像中心部で $9^{\circ} \mathrm{C}$ 低い值であった。

次に，図 8 のレーザーとカメラの位置を入れ替え，計測面を水平断面のガスケット位置に合わせて計測を行っ た. 図 14 は $N e=1500 \mathrm{rpm}, P_{\text {intake }}=0 \mathrm{kPa}, 0 \mathrm{deg} . \mathrm{ATDC}$ における水平断面温度・速度分布を示している. 図左側で は排気から吸気側への流れが見られ，図右側では旋回渦が見られる。垂直断面では明確なタンブル流が見ら れたが, 水平断面ではスワール流(横旋回流)のような大きな流れは見られない. 点火プラグや吸気バルブ近傍 に画像ノイズや輝度が著しく低いことによる測定エラーが見られるが，温度分布は垂直断面と同様にほぼ均 一な温度場である。
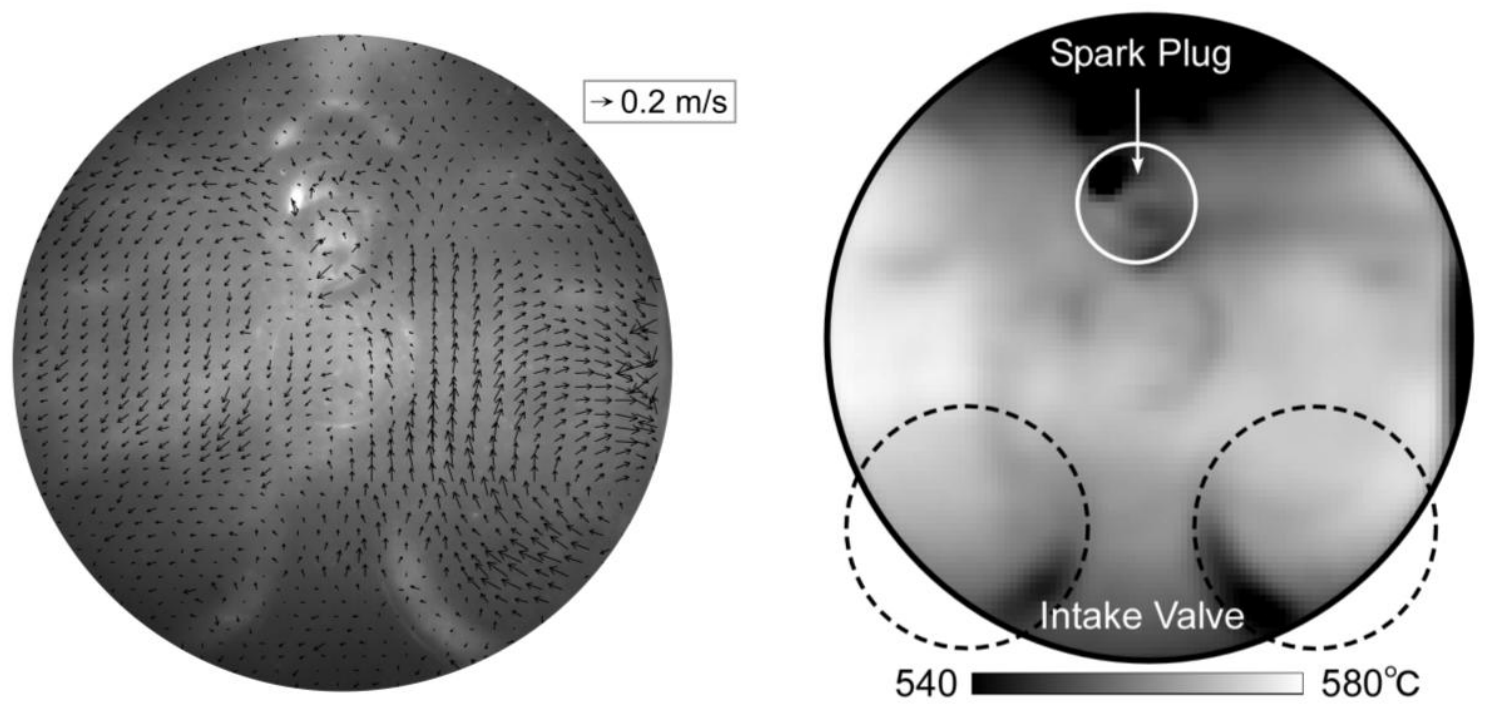

Fig. 14 Gas temperature and velocity field at the horizontal view $\left(N e=1500 \mathrm{rpm}, P_{\text {intake }}=0 \mathrm{kPa}, 0 \mathrm{deg}\right.$.ATDC $)$

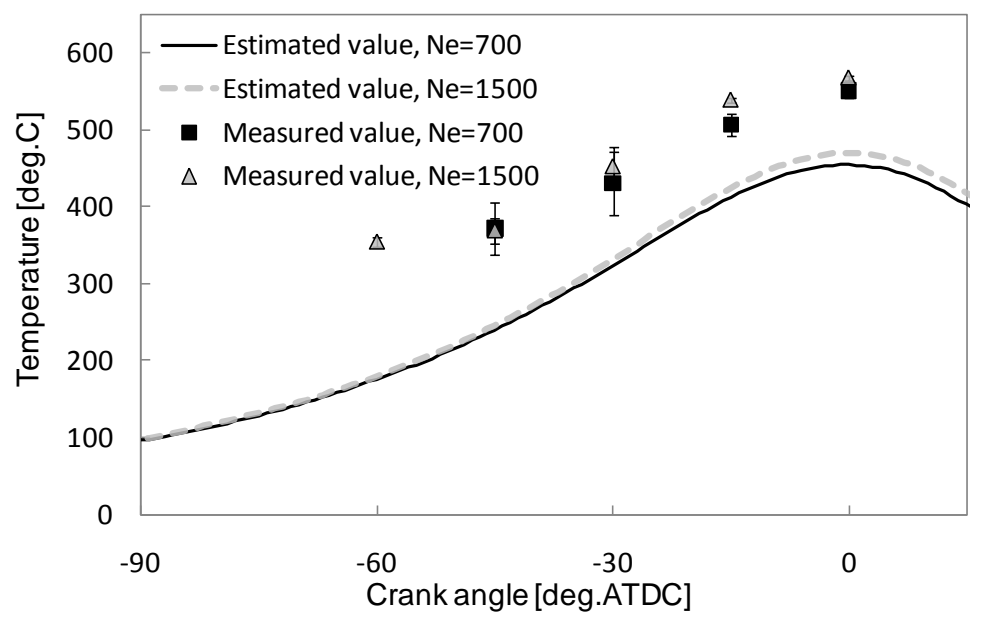

Fig.15 Comparison of measured and estimated gas temperatures (700rpm and 1500rpm Motoring, Horizontal view, MFG)

燐光寿命法により計測した筒内中心部付近(図 10 中の領域(A))の 200 サイクル平均ガス温度と, 筒内圧から断熱圧縮 を仮定して計算したガス温度 $T_{\text {gas ad }}$ を図 15 に示した. エンジン運転条件は 700rpm, $1500 \mathrm{rpm}$ のモータリング, $P_{\text {intake }}=0 \mathrm{kPa}$ で計測断面は水平断面である. なお，測定值のサイクル偏差は小さく， $\pm 1.5^{\circ} \mathrm{C}$ 以下であった. $700 \mathrm{rpm}$ の場合， $\theta=-45 \mathrm{deg} . \mathrm{ATDC}$ で測定值が $372^{\circ} \mathrm{C}$ であり, 圧縮行程が進むとピストンによる断熱圧縮により温度が上昇し, $\theta=0$ deg.ATDC で最大值 $550^{\circ} \mathrm{C}$ となる. この時の $T_{\text {gas_ad }}$ は $458^{\circ} \mathrm{C}$ であり, 測定值は $T_{\text {gas ad }}$ に対して $93^{\circ} \mathrm{C}$ 高い值を示す. しかし, 両者のクランク角に対寸る温度変化は良く一致している. また, エンジン回転数が 700rpm から 1500rpm に増 加しても測定值と $T_{\text {gas } a d}$ はほとんど変化なく, $\theta=0$ deg.ATDC で最大值 $567^{\circ} \mathrm{C}$ となる. クランク角に対する温度変化は いずれの回転数でも良く一致している. 
図 15 に示した測定結果と式(2)より算出したガス温度は差異が大きい．そこで MFG 粒子の追随性，及び 4 節の実験におけるエラーの要因について検討した．まず，MFG 粒子(平均粒子径 4 6 $6 \mu \mathrm{m}$ )の流れに対する追随 性について，ストークス数は 0.1 0.23 とやや大きい值であるが 1.0 よりは小さく, 流れに追随していると考 えられる.流れの振動に対しては，200Hz 以下を主流成分と仮定すると振幅比 $98 \%$ 以上，位相遅れ-5deg. 以下 で追従する，遠心力の影響は小さく，主流には追従すると考えられる．また，MFG 粒子の温度緩和時間につ いて, MFG 粒子の熱拡散率は測定できていないが，類似の蛍光体物質である $\mathrm{Y}_{2} \mathrm{O}_{3}$ の熱拡散率を用いて計算 した結果，90\%緩和時間は $20 \mu \mathrm{s}$ であった。これは測定に要している時間に比べて十分短い. MFG 粒子の空気 に対する体積比率を $10^{-6}$ とすると, 温度変化時に MFG 粒子が受け取る熱量は全体の $0.15 \%$ 以下である. その ため, 流れに対する追随性に問題が残るものの，概して MFG 粒子は流れの温度速度に追従し得ると考えられ る，温度速度への追随性を更に高めるには，より小さい粒子径の蛍光体を利用する必要がある．これらの詳 細及び，燐光粒子画像をPIVに利用することによる影響については別報で詳述する.

MFG 粒子の追随性に大きな問題が見られないことから, 図 15 に示した誤差の要因を別途検討する. 実験 では筒内ガスの温度一様場を作ることができず，その場校正を行うことができなかった．また，図 5 に示し た外校正関数補正のための参照点が取れず,一切の補正を行わずに外校正で得た校正関数(図 9)を直接適用し た. そのため, 温度の絶対值が一致しなかったものと考えられる. 今後, 吸気加熱を行いながら一定温度の 空気と蛍光体を筒内に送り込むなどして，その場校正を実施する必要があると考えられる.

粒子を空間に散布した場合には，固定した粒子を用いた外校正データ取得時に比べて蛍光体粒子の数密度 が低下寸る. 粒子の数密度が低下したことによる燐光強度不足により, 壁面温度計測の場合と比べて画像の $\mathrm{S} / \mathrm{N}$ 比がやや低かったこと, 筒内壁面に付着した蛍光体による励起光や燐光の散乱の影響も考えられる. $\mathrm{SiO}_{2}$ ナノコーティングによってある程度緩和されたものの, MFG 粒子は凝集性・付着性が高く, 観察空に付着し た粒子もエラーの要因になったものと考えられる。これらについては粒子数密度の最適化，粒子の分散性の 更なる向上, 励起光強度・燐光強度・カメラ感度のバランスを調整し, 画像の $\mathrm{S} / \mathrm{N}$ 比を改善することが重要 である. 分散性を向上できれば数密度の制御性も向上するため, $\mathrm{SiO}_{2}$ ナノコートのコート厚さを変化させる など, シーディング性能の改善が必要である.

\section{5. 結 論}

本研究では，無機質蛍光体を用いた燐光寿命法による温度計測と PIV を組み合わせた高温流動場での温度・ 速度同時計測法の開発を行った。

（1）はじめに瞬時壁面温度計測を行い，校正画像を用いて精度を評価した。 その場校正を行った結果, 温度測 定誤差は-2.47 $1.02^{\circ} \mathrm{C}$ であった.

(2) 別サンプルを用いて校正関数を取得し，また，CMOS センサの非線形性等を無視して画像全体に共通の 校正関数を適用寸る外校正の場合, 測定誤差が-9.51 7.10 ${ }^{\circ} \mathrm{C}$ と大きくなった.

(3)壁面温度測定実験で得たモータリング運転時の壁面温度は, 筒内圧から断熱圧縮を仮定して求めたガス温度 変化に応じて変化した。

(4) 本手法によりエンジン筒内の温度・速度の同時計測ができることが確認できた. すなわち, 燐光寿命法によ

りガス温度分布，粒子画像を PIV 解析寸ることにより速度分布を，エンジン筒内で同時に計測できた。

(5) 燐光寿命法で測定した筒内ガス温度について，筒内圧から断熱圧縮を仮定して求めた温度と絶対值が異な

り, 温度の絶対精度は十分でないものの, クランク角に対する温度変化の傾向は良く一致した.

筒内ガス流動の温度・速度同時計測について, 速度計測法は通常の PIV と同様であるため現時点では十分 な評価を行っていないが，今後，同条件における通常の PIV 測定結果との比較や，粒子の追随性などに関す る検討を行い，精度及び適用可能性を詳細に検討する必要がある，温度計測については今後，適切な検証用 データの取得や外校正法の改良, 画像 S/N 比の改善などにより精度を向上し, より定量的で実用的な計測を 実現する必要がある。また，今回はシリンダ内ガス温度がほぼ一様なモータリング運転のみを対象としてガ ス温度計測を行ったが, 今後, 既知の温度分布が存在する高温ガス流れ場を作り, 実験を行う必要がある. 


\section{謝辞}

本研究費の一部は財団法人東電記念科学技術研究所からの助成によるものである. 本研究の一部は科研費 (20760129)および(23360089)の助成を受けたものである.

\section{文献}

(1) Urata Y., Awasaka M., Takanashi J., Kakinuma T., Hakozaki T., Umemoto A., "Study of Gasoline-fueled HCCI Engine Equipped with an Electromagnetic Valve train", SAE technical paper, (2004), 2004-01-1898

(2) Takanashi J., Awasaka M., Kakinuma T., Takazawa M., Urata Y., “A study of A Gasoline HCCI Engine Equipped with an Electromagnetic VVT Mechanism”, Proc. of FISITA 2006 World Automotive Congress, Yokohama, (2006), F2006P360T

(3) Kuboyama T., Moriyoshi Y., Yamada T., Takanashi J., Suzuki M., Hatamura K., "Analysis of the Impact of Spatial Distribution of In-Cylinder Temperature and Fuel Concentration of Combustion Characteristics of the Blow-Down Super Charged HCCI Gasoline Engine", Proc. of the 20th Internal Combustion Engine Symposium Japan, (2009), 20090052

(4) Crimaldi J.P., "Planar laser induced fluorescence in aqueous flows", Experiments in fluids, Vol.44 (2008), pp. 851-863.

(5) Coppeta J. and Rogers C., "Dual emission laser induced fluorescence for direct planar scalar behavior measurements", Experiments in Fluids, Vol.25 (1998), pp.1-15.

(6) Sakakibara J. and Adrian R.J., "Whole field measurement of temperature in water using two-color laser induced fluorescence", Experiments in Fluids, Vol.26 (1999), pp. 7-15.

(7) Sakakibara J. and Adrian R.J., "Measurement of temperature field of a Rayleigh-Benard convection", Experiments in Fluids, Vol.37, No.3 (2004), pp. 331-340.

(8) Someya S. Bando S. Song Y. Chen B. and Nishio M., "DeLIF Measurement of pH Distribution around Dissolving CO2 Droplet in High Pressure Vessel”, Int.J. Heat and Mass Transfer, Vol.48, No.12 (2005), pp. 2508-2515.

(9) Mielke A.F., Elam K.A., "Dynamic measurement of temperature, velocity, and density in hot jets using Rayleigh scattering”, Experiments in Fluids, Vol.47 (2009), pp. 673-688.

(10) Brubach J., Patt A. and Dreizler A., "Spray thermometry using thermographic phosphors", Applied Physics B, Vol.83 (2006), pp.499-502.

(11) Coyle L.M. and Gouterman M., "Correcting lifetime measurements for temperature", Sensors and actuators B, Vol.61 (1999), pp.92-99.

(12) Kissel T., Baum E., Dreizler A. and Brubach J., "Two-dimensional thermographic phosphor thermometry using a CMOS high speed camera system", Applied Physics B, Vol.96 (2009), pp. 731-734.

(13) Omrane A., Ossler F., Alden M., "Temperature measurements of combustible and non-combustible surfaces using laser induced phosphorescence", Experimental Thermal and Fluid Science, Vol.28 (2004), pp.669-676.

(14) Khalid A.H., Kontis K., "2D surface thermal imaging using rise-time analysis from laser-induced luminescence phosphor thermometry", Measurement Science and Technology, Vol.20 (2009), Paper No. 025305.

(15) 小酒英範, 河内陽平, 大西毅, 相澤哲哉, “感熱蛍光体を用いたディーゼル機関燃焼室壁面温度の画像計測”, 日 本機械学会論文集 B 編, Vol. 74, No. 738 (2008), pp. 490-497.

(16) 長谷川亮, 阪田一郎, 柳原弘道, Johansson B., Omrane A., Alden M., “レーザ誘起 Phosphorによる二次元ガス温度 計測”，日本機械学会論文集 B 編, Vol. 74, No. 742 (2008), pp. 1427-1432.

(17) 染矢聡, 倉健太郎, 李艶栄, 岡本孝司, “感温粒子を用いた温度速度分布同時計測”, 日本機械学会論文集 B 編, Vol. 75, No. 758 (2009), pp. 1975-1982.

(18) 染矢聡, 内田光則, 石井慶子, 富永馨, 李艶栄, 岡本孝司, “高速度カメラと燐光感温粒子を用いた寿命法によ る温度速度計測”, 日本機械学会論文集 B 編, Vol.75, No.759 (2009), pp.2207-2214.

(19) Feist J.P., Heyes A.L., Seefeldt S., "Oxygen quenching of phosphorescence from thermographic phosphors", Measurement Science and Technology, Vol.14 (2003), N17-N20.

(20) Brubach J., Dreizler A., Janicka J., "Gas compositional and pressure effects on thermographic phosphor thermometry", Measurement Science and Technology, Vol.18 (2007), pp.764-770. 
(21) 染矢聡, 内田光則, 大倉康裕, 李艶栄, 岡本孝司, “高速度カメラを用いた燐光寿命法による表面温度分布計測”, 日本機械学会論文集 B 編, Vol.76, No.767(2010), pp.1035-1041.

(22) Brubach J., Janicka J., Dreizler A., "An algorithm for the characterization of multi-exponential decay curves", Optics and Lasers in Engineering, Vol.47 (2009), pp.75-79.

(23) Allison S.W., Gillies G.T., "Remote thermometry with thermographic phosphors: Instrumentation and applications", Review of Scientific Instruments, Vol.68(7) (1997), pp.2615-2650.

(24) Khalid A.H., Kontis K., "Thermographic phosphors for high temperature measurements: principles, current state of the art and recent applications", Sensors, Vol.8 (2008), pp.5673-5744.

(25) Mittal M., Sadr R., Schock H.J., Fedewa A., Naqwi A., "In-cylinder engine flow measurement using stereoscopic molecular tagging velocimetry (SMTV)", Experiments in Fluids, Vol.46(2009), pp.277-284.

(26) Fujisawa N., Funatani S. and Katoh N., "Scanning liquid-crystal thermometry and stereo velocimetry for simultaneous three-dimensional measurement of temperature and velocity field in a turbulent Rayleigh-Bernard convection", Experiments in fluids, Vol.38 (2005), pp. 291-303.

(27) Dabiri D., "Digital particle image thermometry / velocimetry: a review", Experiments in Fluids, Vol.46 (2009), pp. 191-241. 